DOI: $10.51480 / 1899-5101.14 .2(29) .7$

\title{
Adolescents on YouTube: gender differences regarding the videos they upload and watch
}

Rebeca Suárez-Álvarez

(iD) ORCID: 0000-0002-0102-4472

Rey Juan Carlos University, Spain

Antonio García-Jiménez

(i) ORCID: 0000-0002-8423-9486

Rey Juan Carlos University, Spain

\author{
Manuel Montes-Vozmediano \\ iD ORCID: 0000-0001-6624-8699 \\ Rey Juan Carlos University, Spain
}

\begin{abstract}
This study examines whether gender is a key factor when producing and uploading audio-visual content to this social network. The research has been carried out using content analysis methodology applied to a sample of 300 videos uploaded to YouTube by adolescents aged 11-17 years, which were collected and analysed during the state of emergency in Spain (13 March - 21 June of 2020) as a result of the COVID-19 pandemic. Contents uploaded by these YouTubers are amusing, and their topics differ significantly depending on the author's gender. Boys focus mainly on playing games, while the range of topics among girls is more diverse. There are no significant differences in the way both genders approach the topic of COVID-19. Channels oriented toward girls are protected from comments their followers might make about them, whereas boys are more exposed to members of the public who view their audio-visual productions.
\end{abstract}

KEYWORDS: YouTube; teenagers; gender; visual consumption, audiences.

\section{INTRODUCTION}

Scientific literature regarding the analysis of YouTube videos has increased in recent years, attracting the interest of the scientific community (García, Catalina \& López de Ayala, 2016; Khan, 2017; Burgess \& Green, 2018; MontesVozmediano, García-Jiménez \& Menor-Sendra, 2018; Pereira, Moura \& Fillol, 
2018). However, there is a scarcity of research related to the types of videos YouTubers upload from a gender perspective. In order to provide insight into this area, the present research is based on an exploratory analysis of the video content recorded by Spanish adolescent YouTubers, with gender being a determining factor.

\section{THEORETICAL BACKGROUND}

\section{CONSUMPTION AND AUDIENCES}

Watching videos has become one of the most common activities for children and minors on the Internet for some years now (Holloway, Green \& Livingstone, 2013). In the case of adolescents, YouTube and Instagram comprise the largest collective social network and space for consumption, and to a lesser extent, for audio-visual production (Anderson \& Jiang, 2018).

As far as the production-creation binomial is concerned, it is clear that minors try to follow the creative patterns of professionals to a large extent (McRoberts, et al, 2016). However, the most common situation is for a user to share videos that have already been broadcast, such as television content, which is quite usual if the political perspective is considered (Berrocal, Campos \& Redondo, 2014; Fontenla-Pedreira, Rúas-Araújo \& Conde-Vázquez, 2020). In other areas, such as the social or cultural realms, the percentage of self-recording or user-generated content is higher. If we look more closely at the adolescents involved in content production, Guerrero-Pico, Masanet and Scolari (2019) mention the existence of three categories of producers: casual, aspirational, and expert, which reflects the degrees from low to high of the types of productions they must confront, the capacity to plan, the use and proposals of narratives, and aesthetic/motivational values.

On the other hand, regarding the YouTuber phenomenon, popularity is presented as one of the factors for understanding audio-visual production on this platform. Valderrama and Velasco (2018) argue this reality could be reinforced in a socio-technical way. The application of algorithms and any resulting successful models could promote combined forms of social recognition. To this should be added the impact of analyses aimed at YouTube audiences that are proposed as an operational and social requirement for achieving fame. All of this is leading to a situation, in which alternative or underground proposals exist, even for children, adolescents and young people, yet in reality the practice is marginal and offers few options for achieving popularity. 


\section{YOUTUBERS, THE NEW IDOLS AND COMMUNICATORS}

YouTubers operate in an ambivalent space, as they must preserve values such as authenticity, closeness, and accessibility for their followers, while at the same time furthering their own self-promotion, or their own brand (Senft, 2012; Abidin, 2015; Smith, 2017). Moreover, as they become more popular, they tend to promote or encourage the acquisition or consumption of other brands or products, which may influence their followers' perception of authenticity. This promotion of products or the inclusion of advertising in non-professional formats even appears in underage YouTubers (Martínez-Pastor, Ongkrutraksa \& Vizcaíno-Laorga, 2020). Indeed, Suárez-Álvarez, García-Jiménez and MontesVozmediano (2021) conclude that YouTube has become an advertising showcase in which minors play a semi-professional role on the creation of their audio-visual productions. These conclusions contradict Fernández and Chamizo (2020) who indicate that the most common situation is the self-promotion of their own brands or products by this type of child or adolescent YouTuber.

Audio-visual content published by YouTubers is now considered a valuable tool capable of contributing to the development of a variety of marketing strategies for the purpose of reaching new audiences through more compelling and far-reaching content (Lopes, et al., 2020). The influence that YouTubers exert on their followers has been studied from varied perspectives. Corrêa et al. (2020) consider that the commitment shown by followers toward YouTubers is related to areas such as cognition, affectivity and behaviour, which lead to a particular connection that affects the intention of followers to use a brand promoted by these YouTubers. Studies show that the audio-visual content of YouTubers generate the most interaction with users who choose to rate and comment on them at levels of participation that are unmatched by videos published by other contributors (Montes-Vozmediano, García-Jiménez \& Menor-Sendra, 2018).

According to Balleys, Millerand, Thoër and Duque (2020), the principle of identification is inherent to the creation of videos made for and watched by teenagers on YouTube. Both creators and viewers are searching for a type of common affinity through a sense of shared intimacy. This occurs within the context of a dual necessity for recognition through the exchange of videos and messages that often have a confessional-intimate nature. In this sense, the public validates YouTubers and sees their own reflection in them, partly as a way of knowing themselves. Indeed, not only do the topics of the videos, which should be interesting for teenagers, encourage this connection, but the platform itself and the videos with a personal/intimate format encourage this link as well. This situation occurs with some ostensibly amateur videos.

Especially for young audiences, YouTubers are capable of being role models with a certain involvement in the development of their identity (Lovelock, 2017; Pérez-Torres, Pastor-Ruiz \& Abarrou-Ben-Boubaker, 2018). However, another 
study carried out among a pre-adolescent audience has not conferred an especially relevant role to YouTubers in the development of identity among minors (Aran-Ramspott, Fedele \& Tarragó, 2018). According to these authors, even though YouTubers are present in leisure activities and are seen as cultural icons, pre-adolescents demonstrate a clearly critical attitude, from which it can be inferred that they do not adopt the values and models of behaviour proposed by the YouTubers themselves.

Djafarova and Rushworth (2017) conclude that the influence exerted by non-traditional celebrities, such as bloggers, YouTube personalities, and "Instafamous" profiles is noticeable among young audiences (their study focused on women in the 18-30 year age range), as they are considered to be more credible, and the strongest impact on these young audiences is due to their ability to relate to these celebrities. However, in terms of a direct influence on the purchase impulse, Instagram celebrities stood out.

The increase in audio-visual consumption is associated with leisure, an area that encompasses the productions of YouTubers. These productions can be compared to other types of creators or broadcasters that appear on YouTube, such as young people themselves, the media, public institutions, or private entities (other than the media). In this context, YouTubers are the producers who publish less videos specifically focused on instruction or prevention (García \& Montes, 2020), and consequently they fail to use their ability to influence the public for these purposes. Nevertheless, the profiles of certain YouTubers do tend to be pedagogical in their communications, and instruction is one particular ingredient they use to gain followers.

In short, YouTubers are successful creators. They are everyday members of adolescent culture, in addition to being the new celebrities who can influence others with regard to their behaviour and opinions (Bonaga \& Turiel, 2016), the language they use, and the way they express themselves (González, 2018). They represent a close role model with which adolescents can identify, and this situation is enhanced when the YouTubers themselves are adolescents (Westenberg, 2016). Therefore, it seems pertinent to study how these micro-celebrities communicate with their peers, especially those who are minors.

\section{GENDER VARIABLE}

As a starting point, this research refers to the study by Fernández-de-ArroyabeOlaortua, Lazkano-Arrillaga and Eguskiza-Sesumaga (2018), in which they confirm that the gender variable is relevant for understanding not only consumption, but also the creation and diffusion of content related to adolescent leisure in different social media. In their research, these authors observe that males prefer to consume content of YouTubers and tutorials focused on video games. 
Moreover, it is precisely in video games where continual violence and sexist behaviour can be noted, and where they are eventually considered to be normal.

As far as females are concerned, their digital behaviour is more oriented toward personal experiences, life events, interest in fashion, and the desire to share content. Other differences include girls also engage in more interpersonal relationships and have greater self-control over their media consumption than boys (Masanet, 2016). Some risks include the loss of a sense of privacy (Montes-Vozmediano, García-Jiménez \& Menor-Sendra, 2018), the impact of aesthetic standards from the world of fashion with specific stylistic ideals, and the continuing stereotyped roles assigned to women (Fernández-de-ArroyabeOlaortua, Lazkano-Arrillaga \& Eguskiza-Sesumaga, 2018). In this sense, some authors point out that such divergences can be diminished in digital consumption compared to the remaining media behaviour (Fernández \& González, 2017).

According to Regueira, Alonso and Da-Vila (2020), who studied the 50 most successful YouTuber accounts in Spain through their Instagram profiles, it is clear that females represent a limited percentage on YouTube channels, with the highest number of subscribers and views, and they have a smaller female audience as well. Adolescent girls are mainly associated with stereotypical roles such as beauty, Draw My Life, and fitness. Consequently, it can be argued that YouTube might be reproducing the types of gender imposition seen on traditional media.

Indeed, as pointed out by Maloney, Roberts and Caruso (2017) and Blanco-Ruiz and Sainz-de-Baranda (2018), YouTube is a space where masculinity predominates in various aspects such as creativity and video production. Moreover, this is a space where the content sustains gender roles by linking specifically feculent humour to males, and cosmetic tutorials to females (Scolari \& Fraticelli, 2017).

At the same time, the situation would improve if development of the types of intimacy were maintained in a binary way based on whatever is considered to be feminine or masculine (Balleys, 2017), yet this is compatible with the growing emergence of phenomena that aim to break the previously mentioned male hegemony (Marôpo, Sampaio \& Mirada, 2017).

\section{OBJECTIVES}

The overall objective of this research is to study the videos that teenagers upload on their YouTube channels as a means of communication among youth from a gender perspective. To achieve this objective, the following points have been studied: the number of videos uploaded by each gender and their periodicity, the type of audio-visual production, the tone (positive, negative or neutral), the video category, topics approached, number of views and comments, as well as references to COVID-19. The research questions are as follows: 
1. Do teenagers upload the largest number of videos to YouTube with the most periodicity?

2. What type of video is uploaded to YouTube according to the differentiation between male and female YouTubers?

3. Are there gender differences in terms of tone, in the sense that the videos published in Spain are positive, negative or neutral?

4. Can differences be found in the categories of videos published by males and females?

5. Do both male and female adolescent YouTubers use varied concepts in their videos?

6. Is there greater interaction regarding the videos (number of views, comments, likes and dislikes) depending on the gender of the YouTuber?

7. Has COVID-19 been mentioned and approached more by male or female teenage YouTubers?

\section{METHODOLOGY}

This research is in line with investigations based on content analysis as a method for analysing YouTube (Baños-González, Tiralaso \& Fernández, 2020; Tur-Viñes, Núñez \& Martínez-Pastor, 2019), and has been carried out using this method and outlined in phases. Firstly, a data-content diagnostic sheet was designed. In the next stage, a database was designed and created, in which the data of the 300 videos analysed were recorded, sufficient size to allow the assessment and validity of the results. It allows to obtain representative results on what volume and type of content teenagers watch and upload to their YouTube channels, and it complies to sampling with standardised conditions. Thirdly, all the videos were viewed. Finally, the information generated by the sample data was analysed.

The criteria defined for the discrimination of the sample under study are as follows: videos with more than 1,000 views per video; up to 15 minutes uploaded to the YouTube social network by Spanish YouTubers between 11 and 17 years of age; more than 1 million followers during the state of emergency decreed by the Spanish government on 13 March 2020 that lasted until 21 June 2020 (the last day of the extraordinary situation). The profiles (girls/boys) that met the criteria were analysed during the set period. Determination of the age of adolescence is defined by the World Health Organization ([WHO], 2020) as the stage of growth and human development between 10 and 19 years of age, and the United Nations Children's Fund ([UNICEF], 2020) segments this period into three stages: early (10-13 years), middle (14-16), and late adolescence (17-19). Thus, 11 YouTubers in this study are in early adolescence, 7 are in middle-adolescence, and 1 is in late adolescence at 16 years of age. In this research, the age of the YouTubers has not 
exceeded the legal age for the purpose of discovering what contents are being uploaded by adolescent boys and girls in the age range of minors.

The number of followers has been obtained by reviewing each profile of the YouTubers, and the age has been confirmed by searching in the "more information" section in the profiles of the YouTubers themselves, Google searches, and where possible, in their videos on the YouTube channel (see Table 1).

Table 1. Youtubers analysed

\begin{tabular}{|c|c|c|c|c|}
\hline Username & Age & Gender & $\begin{array}{l}\text { Subscriptions } \\
\text { in millions }\end{array}$ & $\begin{array}{c}\text { No. of videos } \\
\text { analysed }\end{array}$ \\
\hline Adexe \& Nau & 14,16 & Boy & 10.90 & 16 \\
\hline La Diversión de Martina & 15 & Girl & 4.01 & 10 \\
\hline Ariann Music & 14 & Girl & 3.96 & 14 \\
\hline The Crazy Haacks & $15,14,11$ & 2 boys, 1 girl & 3.66 & 29 \\
\hline Sparta356 & 16 & Boy & 3.51 & 4 \\
\hline Alexity & 11 & Girl & 3.49 & 19 \\
\hline Karina \& Marina & 12 & Girl & 3.12 & 26 \\
\hline TeamNico & 11 & Boy & 2.77 & 4 \\
\hline Jugando con Aby & 11 & Girl & 2.71 & 1 \\
\hline El Mundo de Clodett & 11 & Girl & 2.60 & 12 \\
\hline AleGame22 YT & 17 & Boy & 2.59 & 8 \\
\hline Annie Vega & 13 & Girl & 2.53 & 12 \\
\hline DivertiGuay & 11 & Girl & 2.38 & 17 \\
\hline Lady Pecas & 11 & Girl & 1.92 & 16 \\
\hline Acenix & 14 & Boy & 1.81 & 4 \\
\hline Pino & 13 & Boy & 1.77 & 34 \\
\hline Daniela Golubeva & 13 & Girl & 1.77 & 17 \\
\hline TheExaL04 & 16 & Boy & 1.43 & 30 \\
\hline Silvia Sánchez & 13 & Girl & 1.13 & 27 \\
\hline
\end{tabular}

Source: Authors' own data

To make the gender comparison, the videos were coded on the basis of the gender of the YouTubers (boy or girl) and their identification was made by viewing all of the videos to confirm their authorship. In order to present the data in a homogeneous way for all the elements of the sample, a review was carried out on 30 June 2020 regarding the popularity ranking of the YouTubers, the number of reproductions, the number of likes and dislikes, and the number of comments (if admitted).

Once the categories in the database had been chosen, the criteria were set for the sample population: teenage YouTubers between 11 and 17 years of age; videos 
of up to 15 minutes; more than 1 million followers; and more than 1,000 plays per video- by. The sample was coded by assigning numbers to the categories and analysed through a univariate descriptive statistical analysis that allows for the measurement of the distribution and frequency of the values of each variable distributed in the categories.

In order to analyse this digital cultural system that YouTube has become, in which adolescents communicate, share, access information and engage in play, a hierarchical exploration order of seven levels was established.

First, the number of videos published, and their periodicity have been studied. Second, each video was defined by $t$ according to eight categories of topic segmentation of the contents of the videos as follows: (i) video games, (ii) choreography or music videos, (iii) videos with typical teenage scenes, (iv) amusing videos that show actions that try to entertain, (v) testimonies, (vi) tutorials that explain the process of carrying out some kind of activity, (vii) videos with animals or pets, and (viii) videos in which the influencer expresses his or her opinion to their followers on a topic (Yarosh, et al, 2016). A challenge category (Khasawneh, et al, 2021) is added, which includes those actions that with a viral trend, the YouTuber performs a challenge whose purpose is to get more likes. In this case, for example, the challenges can consist of obeying their parents for a day, getting their brother or sister to do his homework, or killing 100 or 1000 characters in Fornite to win a financial prize given by their mother or father.

Third, the tone category of the videos is divided into 3 groups: positive when the message transmits the intention of solving a problem or issue; negative when a fact or situation is exposed as something undesirable; and neutral includes those videos that only explain or describe an action without giving an opinion.

Fourth, the grouping known as category has been analysed, which includes the possibility of videos being entertaining, informative, instructional, and preventive. Fifth, divergence in the treatment of topics was examined by carrying out an analysis of the 20 most recurrent concepts of all the videos from the point of view of the author's gender. Sixth, the interactions received by each video have been registered, accounting for the number of views, likes and dislikes, and comments received for each video. Finally, the seventh level, this study examined references made by adolescents to the coronavirus situation in the videos they uploaded to YouTube during the state of emergency. The aim of this level was to discover the degree of importance they place on the social reality they were experiencing and whether they expressed this to their followers. To complete this point, a time pattern was developed to show video uploads according to date as well as trend lines during the summary period. 


\section{FINDINGS}

\section{NUMBER OF VIDEOS AND PERIODICITY BY GENDER}

The channels are categorized according to the gender of the YouTubers: either girls or boys. A total of 300 videos were analysed, of which 180 are from girls (60\% of the total) and 120 from boys ( $40 \%$ of the total). The channel known as "The Crazy Haacks" contributed 29 videos to the sample, of which 20 were from the two boys and 9 from the girl. Of this total, there are significant differences in the number of videos uploaded according to age. One can observe that at the lower ages, the girls contributed more videos than the boys. However, even though boys uploaded fewer videos of the total number, they are the leaders in video uploads in the greatest age range. This occurred because none of the 16 - and 17-year-old Spanish female YouTubers whom the study analysed have more than 1 million followers and were therefore excluded from the study. Girls aged 11 to 13 years of age uploaded 156 videos (86.7\% of their gender) compared to 38 videos for boys ( $31.7 \%$ of their gender) of the same age. From 14 to 15 years of age, video production tends to be fairly equal between boys (32 videos) and girls (24 videos). In the 16-17 age range, boys are more prolific than in younger ages, offering 50 videos that reach $41.1 \%$ of their audio-visual productions (see Figure 1).

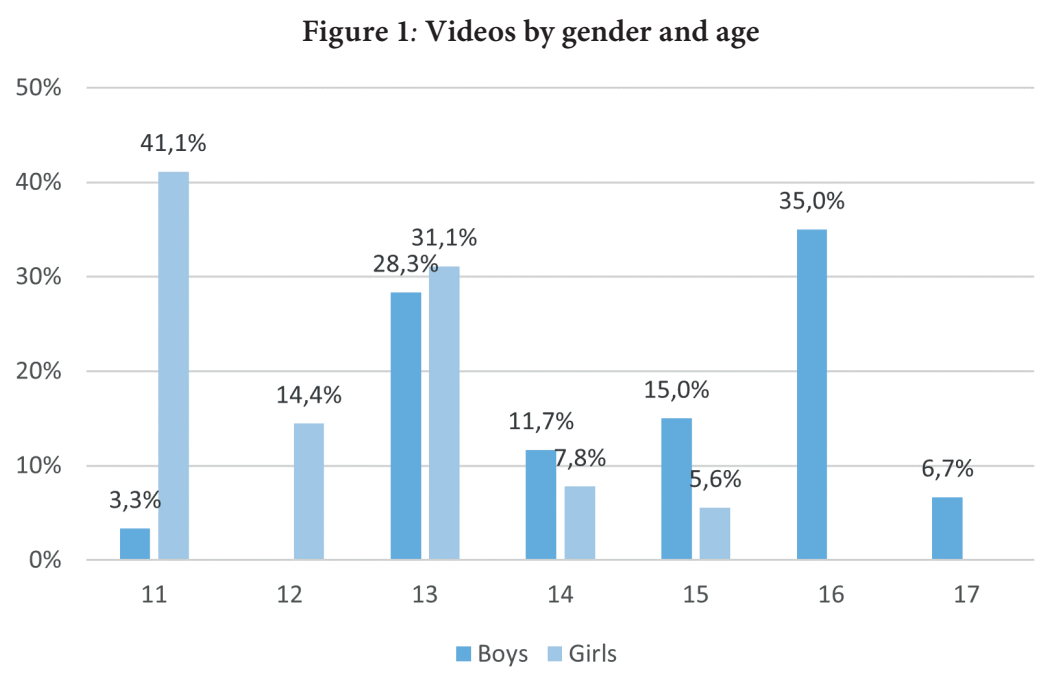

Source: Authors' own research data

In terms of periodicity, $94 \%$ of teenage YouTubers upload an average of 1 to 3 videos per week. A total of 3 YouTubers increased their production to an average of 4 to 5 videos per week for two weeks during the state of emergency: 
they included one boy (TheExaL04, 16 years old) and two girls (Alexity, 11 years old; Karina and Marina, 12 years old).

\section{VIDEO TYPE}

The videos uploaded by the Spanish YouTubers combine different types of content. They share videos that are edited and of high quality, which confirms that the audio-visual productions they upload to this social network are well-developed, and not the result of improvisation. Boys and girls both contribute mostly amusing videos in similar percentages. The girls contributed 105 productions (45.3\% of their gender), whereas the boys contributed 61 (42.3\% of their gender). It bears mentioning that the 50 videos dedicated to video games in which YouTubers show their skills playing real games were all contributed by boys (41.1\% of their gender), yet the girls are the leaders among the rest of the video types (see Figure 2).

Figure 2. Video typology

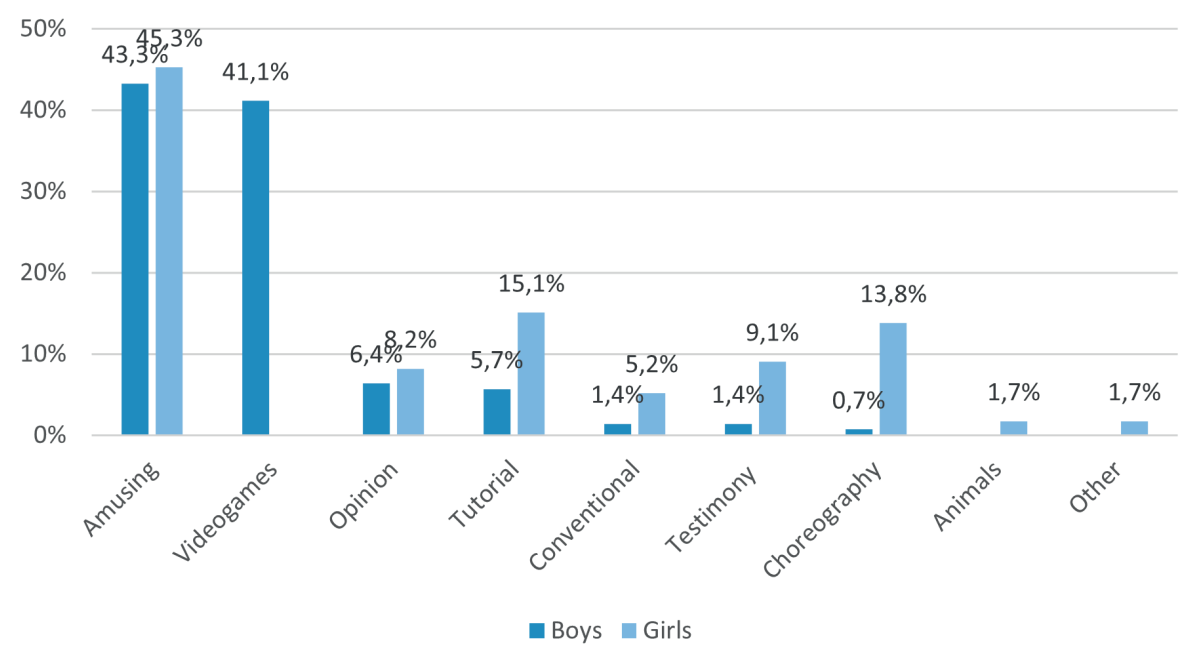

Source: Authors' own research data

By delving into more detail, we can see that in the case of boys who upload videos to their YouTube channels while playing video games (Fortnite and Minecraft), not only do they play, but they also talk while they play, narrate what they are doing, make jokes, and perform actions not directly related to the game, such as a certain amount of conversation with a relative who is present, and is usually a brother or the mother. During the games, they manage to develop communication skills with their followers and increase their strategic competence, decision-making skills, spatial-temporal perception, and their ability to process information, as well as competence in reading virtual maps. 
In the case of girls, the topics are more diverse. Videos of the teenage girls focus mainly on tutorials ( $n=35$ compared to $n=8$ for the boys). These videos explain the procedures of some particular activity, how a product works, how to perform some beauty treatment, or tutorials related to choreography or music videos ( $n=32$ compared to $n=1)$, in which they dance and demonstrate their skills in this area. The girls display practices in their videos that may be of interest to their audience or help them improve their communication skills, and they sometimes interact with family members who are usually parents or siblings.

The girls are involved in the issues that interest them and are affectionate toward their audience. In their videos, they take a position on a topic or issue in 21 videos (compared to 2 for boys), express their opinions in 19 videos (compared to 9 for boys), and show conventional scenes from their daily lives in 12 productions (compared to 2 for the boys). Animals are not a topic of interest to boys, as none of their videos contain this theme, compared to teenage girls who submitted 4 videos of this type.

\section{TONE OF THE VIDEOS PUBLISHED}

The tone of the videos has been categorized into positive, negative and neutral. They are considered to have a positive tone when the YouTubers try to solve a problem or give recommendations on how to confront a challenge in Fortnite, how to make a sandwich without a toaster, or how to give a fresh smell to a cupboard. Videos with a neutral tone are limited to those, in which boys play an online game while explaining what they are doing without taking a position on its content or on the actions they are carrying out. In the case of girls, videos are considered to be neutral when they demonstrate an activity such as a beauty treatment, in which they comb their hair or put makeup on their faces without revealing their opinion about the activity. Regarding a negative tone, none of the videos uploaded to YouTube by teenage boys and girls has had a negative tone, in which an undesirable situation, non-constructive action, or violent situation was shown. Videos made by the girls are more likely to solve a problem or address an issue that may be of interest to their audience than videos created by boys. Female YouTubers shared 111 positive videos, representing more than $60 \%$ of their gender $(61.7 \%)$, and boys shared 65 videos, representing more than $50 \%$ of their gender (54.2\%). Fewer videos with a neutral tone were registered. Girls shared 69 videos that were neutral compared to 55 for the boys (see Figure 3). 
Figure 3. Video tone

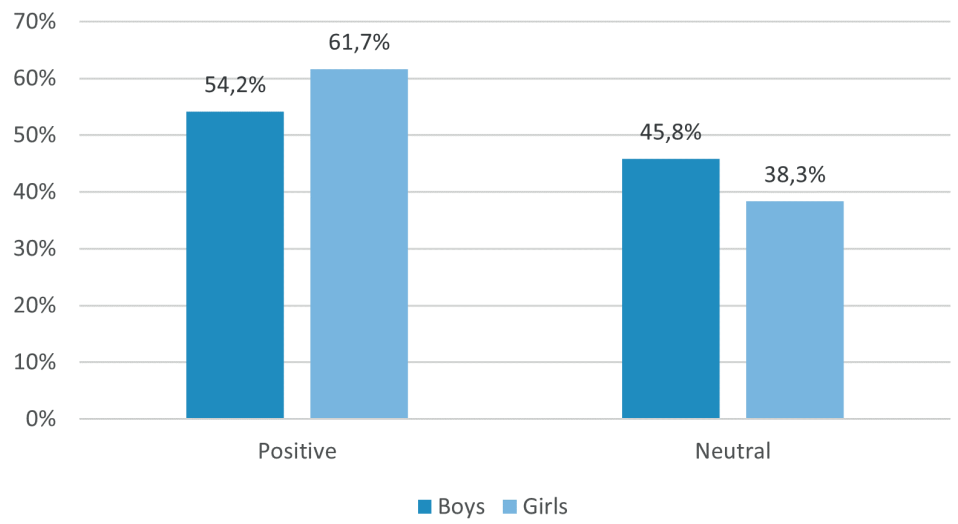

Source: Authors' own research data

\section{VIDEO CATEGORY}

The videos that teenagers record to upload to YouTube are mainly for entertainment purposes. The boys lead the way with 117 videos (85.4\% of their gender). Even though the girls upload more videos with 155 productions, this number is proportionally lower ( $70.1 \%$ of their gender). Both genders combine this type of video with content that is informative and instructional, yet teenage girls prefer to give their videos more informative features ( $n=54$ girls; $n=15$ boys). Regarding the instructional category, ( $n=6$ girls; $n=4$ boys), and the preventive category for situations of risk ( $\mathrm{n}=6$ girls; $\mathrm{n}=1$ boys), almost no attention was paid to these classifications by either gender group (see Figure 4).

Figure 4. Video category

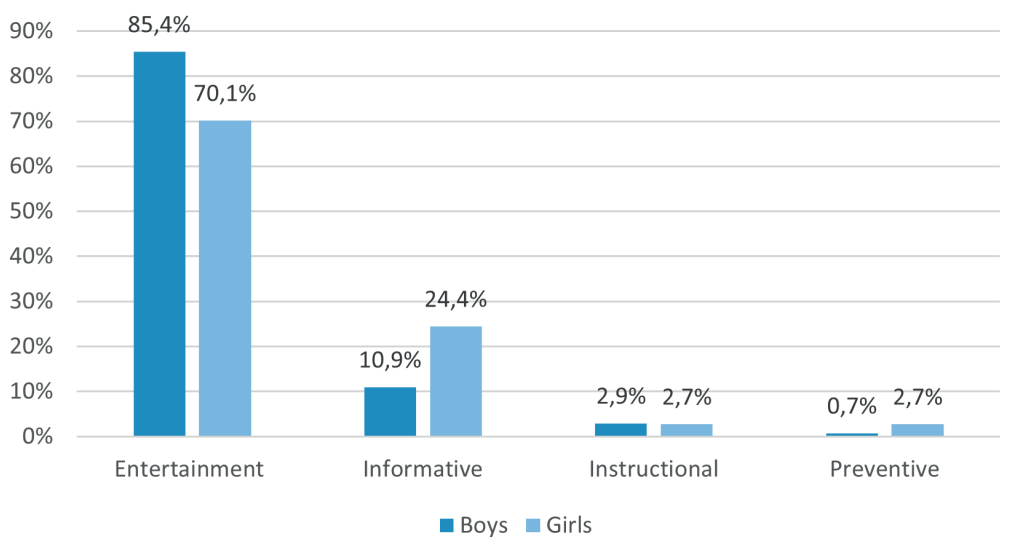

Source: Authors' own research data 


\section{INTERESTS ACCORDING TO GENDER}

Analysis of the interests has uncovered the most relevant aspects of the topics approached by the sample. In order to achieve this objective, the 20 most recurrent concepts in each video have been observed based on the gender of the creator. In the case of both boys and girls, the level of interest by gender has been distinguished according to the diverse challenges faced (boys focused mainly on video games while girls directed their attention toward beauty, food and family), as well as a high level of family participation in the recording (mother, father, brother, or sister), or with these same family members acting as co-stars in the videos.

In the case of boys, the interests most often recorded are connected to video games (13.4\%), Fortnite (12\%), Minecraft (3.8\%), and skin (1.9\%) in reference to the video game Fortnite, for a total of $31.1 \%$. Next, the most frequently discussed topics were facing challenges (16.1\%) and jokes (5.2\%). Regarding the family, participation or reference to a sibling (5.2\%), mother (4.4\%), references to the family in general or to some other relative (3.8\%), and to the father $(2.5 \%)$ stand out, for a total of $15.9 \%$ (see Figure 5).

Figure 5. Frequency of interests in boys' YouTube channels, by percentages

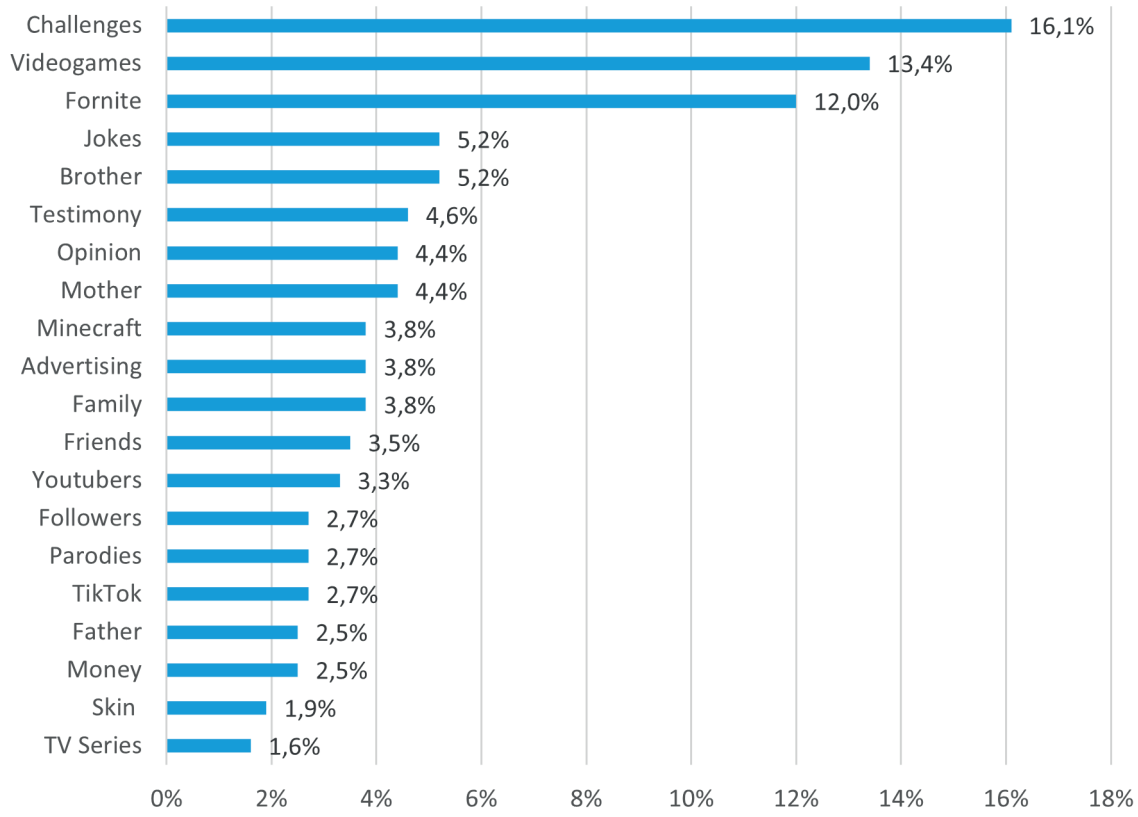

Source: Authors' own research data

In the case of girls (see Figure 6), their videos show a greater dispersion of the main interests featuring in the videos they uploaded to YouTube. Among them, the most outstanding interest at $11 \%$ is the social network TikTok, followed 
by facing 'challenges' (10.7\%). Next, they focus on giving testimonies (10\%), and similar to the case of the videos made by male adolescents, the participation of a family member is also relevant, and is distributed as follows: mother (8.9\%), reference to the family in general or to some other relative $(3.3 \%)$, a partner (3\% [an interest that does not appear in the videos made by boys]), and a sister (2.1\%), for a total of $17.3 \%$ (see Figure 6).

Figure 6. Frequency of interests in girls' YouTube channels, by percentages

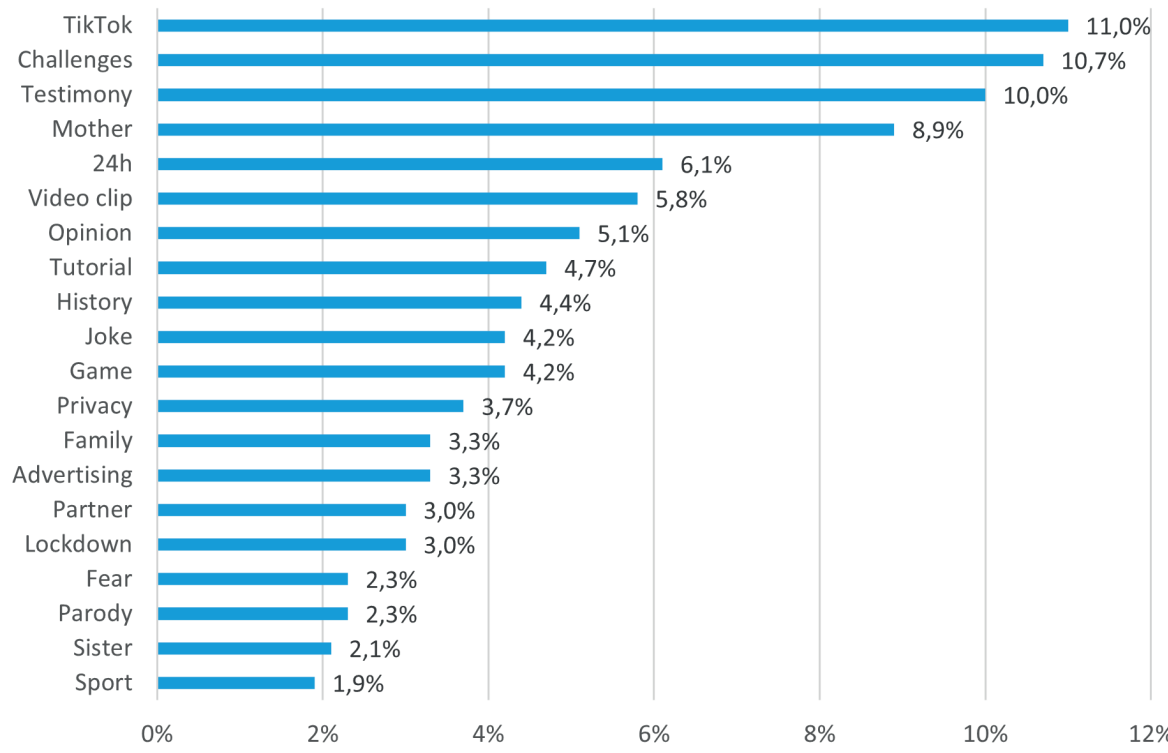

Source: Authors' own research data

\section{VIDEO INTERACTION}

The criteria for classifying the interaction of the videos are based on the evaluation and calculation of the number of views, likes and dislikes, and comments obtained by each video analysed.

The number of views reached more than 150 million $(150,445,346)$, which shows the incredible magnitude of the potential impact their content has on their followers. Among them, it is worth noting that of the 11 solo girls' channels only one (Ariann Music) allowed fans to write comments on the videos they watched. In the case of the boys, the opposite is true. Of the 8 boys' channels, which included The Crazy Haacks (where the two older siblings are boys) all but one (TeamNico) allowed their followers to write comments about the content they watched, thereby exposing themselves to what the audiences may think of them. This blockade of comments on most of the channels belonging to girls 
does not allow for an effective comparison in the comment category to confirm which channels receive the most interaction from their audience.

Regarding the possibility of clicking on like or dislike in relation to the videos being watched, all channels except one (Silvia Sánchez, 13 years old) allowed fans to do so and to express whether they like or dislike what they are watching. The total number of interactions is more than 7 million $(7,067,209)$, and among both girls' and boys' channels, they are overwhelmingly likes, with figures exceeding $95 \%$. It is worth noting that despite the lower number of videos contributed by the boys, they received a higher level of interaction. The boys received 3,782,424 likes and 179,350 dislikes, whereas the girls received 2,951,823 likes and 153,612 dislikes (see Figure 7).

Figure 7. Likes and Dislikes in the YouTube videos

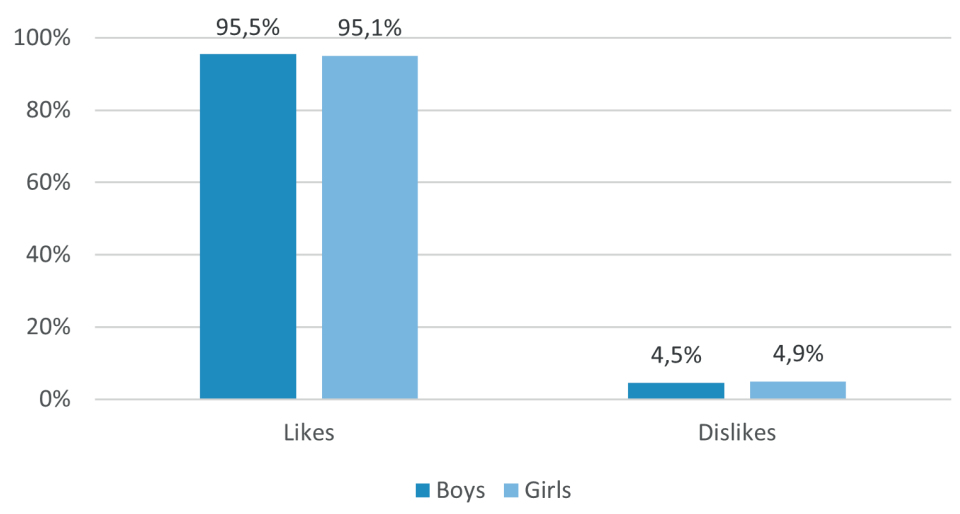

Source: Authors' own research data

\section{HOW BOYS AND GIRLS ADDRESSED THE COVID-19 SITUATION}

From 13 March 2020, the day when the President of the Government announced the state of emergency, until it ended on 21 June 2020, there were no significant differences with regard to references or approaches taken toward the coronavirus situation according to gender. A total of 55 audio-visual productions made by the girl YouTubers ( $31 \%$ of their gender) and 40 made by the boys ( $33 \%$ of their gender) refer to the situation the country was experiencing due to the coronavirus pandemic. The remaining videos do not deal with the pandemic nor its effects.

However, by observing the temporary pattern during the state of emergency in Figure 8, it is possible to see that at the beginning of the state of emergency adolescent girls uploaded more videos that discussed or dealt with the COVID-19 situation than boys. Even though peaks of interest were detected during the period of state of emergency, the relevance of the coronavirus situation gradually decreased. Similarly, the trend line indicates a sustained tendency 
among girls regarding this subject during the time range studied, and as the boys' interest in this subject diminished as the days passed, they displayed a downward trend in this area (see Figure 8).

Figure 8. COVID-19 addressed in the adolescents' videos

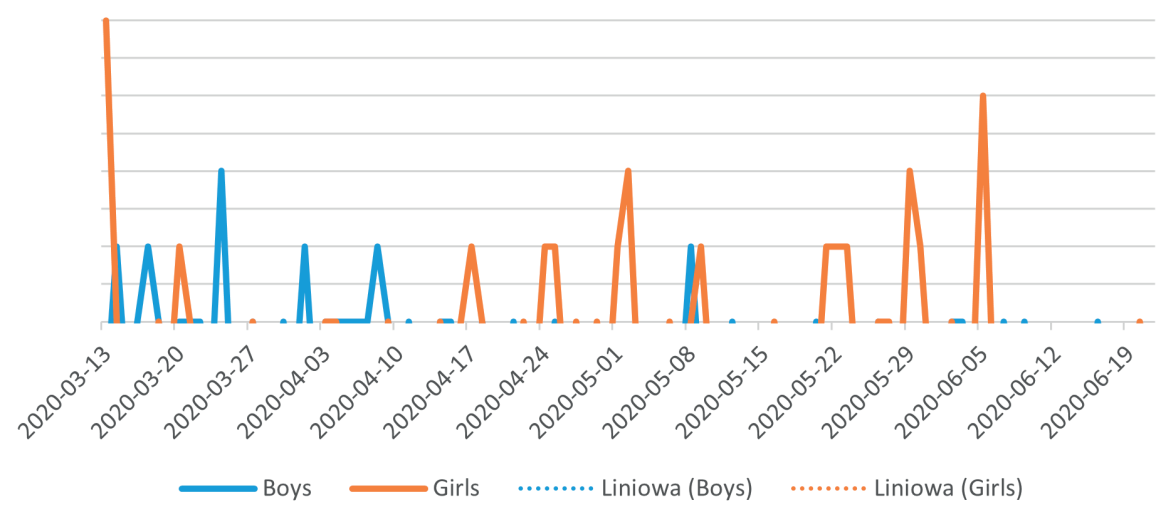

Source: Authors' own research data

\section{DISCUSSION AND CONCLUSIONS}

The underage influencers analysed in the study are what Guerrero-Pico, Masanet and Scolari (2019) call expert producers whose productions are elaborate audio-visual pieces which seek to generate a community of followers with whom to share their experiences, as Balleys et al. (2020) point out. Girls between 11 and 15 years of age are the most prolific video creators among the YouTuber sector under study. They do not, therefore, reflect the parameters of under-representation of females reported in other studies such as that of Regueira, Alonso \& Da-Vila (2020) who conclude that YouTube was reproducing the sexist patterns of the traditional media.

However, when girls reach the ages of 16 and 17, they are no longer present on this social network, and not a single female YouTuber with 1 million or more followers has been registered. Along these same lines, it is evident that female YouTubers are concentrated in the 11-13 years age group (their presence is scarce from the age of 14 onward), while the boys start to gain their share of influence between the ages of 13 and 17 .

If this trend were to continue in the coming years, we would find a lower presence of outstanding female YouTubers. It seems that 16 and 17-year-old girls are contributing more audio-visual productions on TikTok (Suárez-Álvarez 
\& García-Jiménez, 2021), which could give rise to adolescents' migration towards this new digital native social network, as Mercedes (2015) and Angulo, et al., (2019) point about migrating of young people from Tuenti, Facebook and Snapchat to Instagram. The scientific community should continue investigating to confirm whether this migration actually occurs and whether girls are leading the way. It would be interesting to monitor these creators in order to gain knowledge regarding their lack of interest in publishing on this platform as their age increases and find out why this is happening.

On average, girl YouTubers have three more videos per author compared to their boy counterparts. However, this is not because they publish more regularly, as nearly all YouTubers release between 1 and 3 videos per week.

As far as typologies are concerned, amusing videos are by far the most highly represented overall among both genders. Once this common priority interest has been defined, female YouTubers show greater diversity in the typology of content they approach, while male YouTubers only have one other significant alternative typology: audio-visuals related to video games, a preference detected in studies such as that of Fernández-de-Arroyabe-Olaortua et al (2018). Behaviour that does not coincide on TikTok where boys do not create or share video games, but rather focus on viralized audio-visual productions with greater self-representation (Suárez-Álvarez \& García-Jiménez, 2021).

In any case, there are only three categories in girl's productions and two in boy's that exceed 10 percent of production in both genders. The three main typologies among female YouTubers are amusing videos tutorials, choreography and music videos, while among male YouTubers, the typologies that stand out are amusing videos and video games. Except for this last typology, which has no equivalent among female adolescent YouTubers, the audio-visuals produced by female YouTubers predominate in the rest of the typologies. Some repetition of gender roles associated with girls has also been observed (Regueira, Alonso, \& Da-Vila, 2020; and Scolari and Fraticelli, 2017) for the publication of tutorials on beauty. However, more significant is the finding that confirms the greater typological diversity of their audio-visuals, and that amusing videos predominate in both female and male YouTubers.

If we analyse the tone of the videos, the first thing that stands out is the absence of videos with a negative tone. Moreover, a positive tone dominates (as opposed to the third category, the neutral tone) among both boys and girls. However, girl YouTubers are prominent in the use of a positive tone (more than $60 \%$ of their videos have this tone), while in the case of boys, the figures are more uniform: $54.2 \%$ are positive videos and $45.8 \%$ are neutral. Therefore, a less neutral discourse predominates in the case of girl YouTubers in which a constructive approach prevails with the intention to contribute to the solution of a problem, or to actually resolve a problem or situation. 
In the context of the video category, YouTube has consolidated itself as an entertainment platform, a status it has held for over a decade, which is in line with the results from Bañuelos (2009) y Murolo (2010). Two thirds of the videos published by teenage YouTubers belong to the video category, which is clearly predominant among teenage YouTubers of both genders. The topics addressed in their videos emphasise this desire for amusement among teenagers, as stated by García and Montes (2020), and certify the difference in gender as a key factor in audio-visual production on this digital platform. Although both genders show their predilection for performing and recording challenges and have the participation of some family members in their content, the disparity of interests between girls and boys has also been confirmed. Boys focus on video games and making jokes, while girls direct their attention toward other social networks such as TikTok, where they dance, pose, perform, and express their testimonies on topics that concern them.

When analysing the interactions received by teenage YouTubers one may notice that although the boys provide fewer videos, their audience is clearly more active, provide a higher number of clicks on the like, and dislike options. Regarding the pandemic, boys and girls were similar in the way they mentioned the situation in their videos. References to COVID-19 did not reach even a third of the videos among either gender. However, there was an appreciable difference in the declining interest in the pandemic among boy YouTubers, while girl YouTubers made references to COVID-19 relatively consistent throughout the state of emergency. The boys seemed to follow certain patterns of novelty or opportunity, such as when an issue was headline news, while the girls seemed more interested than boy YouTubers in addressing the issue at the beginning of the pandemic, and demonstrated more regularity in their comments. The results support the conclusions by Garcia and Montes-Vozmediano (2020) about the creation of preventive or formative contents, but only in the case of girl YouTubers.

This study has limitations, specifically the selection criteria for the videos of a maximum duration of 15 minutes. This resulted in the exclusion from sample, and thus analysis, of many audio-visual creations related to video games published by adolescent YouTubers, as this type of video is usually of longer duration. However, the characteristics of these audio-visual productions and the preference among the boy YouTubers for these kinds of videos are equally evident. Although the selection criteria for audio-visuals to have a minimum of a thousand views can also be biased. We consider this to be a relevant, but not excessively demanding figure as we did deal with channels that have more than 1 million followers. Consequently, this number of views has allowed us to ensure that we analysed videos that have attracted sufficient interest and have experienced a certain degree of dissemination. 


\section{FUNDING}

This research is part of the project entitled "Social networks, adolescents and young people: convergence of media and digital culture (CSO2016-74980C2-2-R)", and the project entitled, "New scenarios of digital vulnerability: media literacy for an inclusive society" (PROVULDIG-2-CM) (ref. H2019/HUM5775), the Autonomous Region of Madrid (CAM) and the European Social Fund $(01 / 01 / 2020-31 / 12 / 2022)$.

\section{REFERENCES}

Abidin, C. (2015). Communicative Intimacies: Influencers and Perceived Interconnectedness. Ada, 8, 1-16. Retrieved from https://adanewmedia.org/2015/11/issue8-abidin/

Anderson, M., \& Jiang, J. (2018). Teens, social media \& technology 2018. Pew Research Center. Retrieved from www.pewinternet.org/2018/05/31/teens-social-media-technology-2018/

Angulo, C., Espinoza, P., Manayay, A., \& Valencia, M. (2019). La migración a Instagram desde Facebook y Snapchat [The migration to Instagram from Facebook and Snapchat]. In Universidad de Lima, Facultad de Comunicación (Ed.). (2019). Concurso de Investigación en Comunicación: trabajos ganadores [Competition in Communication Studies: winning projects], (pp. 183-198). Universidad de Lima.

Aran-Ramspott, S., \& Fedele, M., Tarragó. A. (2018). Funciones sociales de los Youtubers y su influencia en la preadolescencia [Youtubers' social functions and their influence on pre-adolescence]. Comunicar, 57, 71-80. https://doi.org/10.3916/C57-2018-07

Balleys, C. (2017). Teen boys on YouTube: Representations of gender and intimacy. In R. Andreassen, M.N. Petersen, K. Harrison, \& T. Raun, T. (Eds.), Mediated intimacies: Connectivities, relationalities and proximities (pp. 227-239). Routledge. https://doi.org/10.4324/9781315208589

Balleys, C., Millerand, F., Thoër, C., \& Duque, N. (2020). Searching for Oneself on YouTube: Teenage Peer Socialization and Social Recognition Processes. Social Media+ Society, 6(2), 20-56. https://doi. org/10.1177/2056305120909474

Baños-González, M., Tiralaso, H. C., \& Fernández, M. R. (2020). La difusión del vídeo musical en YouTube. Análisis de la capacidad viral del vídeoclip [The broadcast of the music video on YouTube. Analysis of the viral capacity of the video clip]. Revista Latina de Comunicación Social, 77, 117-141. https://doi.org/10.4185/RLCS-2020-1452

Bañuelos, J. (2009). YouTube como plataforma de la sociedad del espectáculo [YouTube as a platform for the entertainment society]. Razón y Palabra, 69, 1-25. https://goo.gl/XJpyrz

Berrocal, S., Campos, E., \& Redondo, M. (2014). Media prosumers in political communication: Politainment on YouTube. Comunicar, 43, 65-72. https://doi.org/10.3916/C43-2014-06

Blanco-Ruiz, M., \& Sainz-de-Baranda, C. (2018). Channels produced by LGBT+ Youtubers: gender discourse analysis. Observatorio $\left(\mathrm{OBS}^{*}\right)$, 12(SPE1), 97-121. https://bit.ly/2GnNUzz

Bonaga, C., \& Turiel, H. (2016). Mamá, iquiero ser YouTuber! [Mum, I want to be a YouTuber!]. Planeta. Burgess, J., \& Green, J. (2018). YouTube: Online video and participatory culture. John Wiley \& Sons. 
Corrêa, S.C.H., Soares, J.L., Christino, J.M.M., Gosling, M.D.S., \& Gonçalves, C.A. (2020). The influence of Youtubers on followers' use intention. Journal of Research in Interactive Marketing, 14(2), 173-194. https://doi.org/10.1108/JRIM-09-2019-0154

Djafarova, E., \& Rushworth, C. (2017). Exploring the credibility of online celebrities' Instagram profiles in influencing the purchase decisions of young female users. Computers in Human Behaviour, 68, 1-7. https://doi.org/10.1016/j.chb.2016.11.009

Fernández Torres, M. J., \& Chamizo Sánchez, R. (2020). YouTuber infantiles, los nuevos protagonistas de la comunicación comercial [Children's YouTubers, the new protagonists of commercial communication]. In Liberal y Mañas (Eds.), Las redes sociales como herramienta de comunicación persuasiva [Social media as a persuasive communication tool], (pp. 311-340). McGraw-Hill.

Fernández, B. F., \& González, A. G. (2017). Analysis of Children Consumption of TV, Videogames and the Internet: Differences Based on Gender in their Selection of Audiovisual Content. Fonseca, Journal of Communication, 15, 95-108. https://doi.org/10.14201/fjc20171595108

Fernández-de-Arroyabe-Olaortua, A., Lazkano-Arrillaga, I., \& Eguskiza-Sesumaga, L. (2018). Digital natives: Online audiovisual content consumption, creation and dissemination. Comunicar. Media Education Research Journal, 26(2). https://doi.org/10.3916/C57-2018-06 |

Fontenla-Pedreira, J., Rúas-Araújo, J., \& Conde-Vázquez, E. (2020). Audiencia en redes sociales de los debates televisados en las elecciones generales de abril de 2019 [Social media audience of televised debates in the general elections of April 2019]. Revista Latina de Comunicación Social, 76, 1-16. https:// www.doi.org/10.4185/RLCS-2020-1434

García Jiménez, A., \& Montes Vozmediano, M. (2020). Subject matter of videos for teens on YouTube. International Journal of Adolescence and Youth, 25(1), 63-78. https://doi.org/10.1080/02673843.201 9.1590850

García Jiménez, A., Catalina García, B., \& López de Ayala, M. C. (2016). Adolescents and YouTube: creation, participation and consumption. Revista Prisma Social, 1, 60-89. https://revistaprismasocial.es/article/view/1314

González Gómez, O. (2018). Análisis de la narrativa audiovisual de los Youtubers y su impacto en los jóvenes colombianos [Analysis of the audiovisual narrative of Youtubers and its impact on young Colombians]. Doctoral theses: Universidad de Málaga. https://hdl.handle.net/10630/16794

Guerrero-Pico, M., Masanet, M. J., \& Scolari, C. A. (2019). Toward a typology of young produsers: Teenagers' transmedia skills, media production, and narrative and aesthetic appreciation. New Media \& Society, 21(2), 336-353. https://doi.org/10.1177/1461444818796470

Holloway, D., Green, L., \& Livingstone, S. (2013). Zero to eight: Young children and their internet use. https://bit.ly/3hUG0vD

Khan, M. L. (2017). Social media engagement: What motivates user participation and consumption on YouTube? Computers in human behaviour, 66, 236-247. https://doi.org/10.1016/j.chb.2016.09.024

Khasawneh, A., Madathil, K. C., Zinzow, H., Wisniewski, P., Ponathil, A., Rogers, H., Agnisarman, S., Roth, R. \& Narasimhan, M. (2021). An Investigation of the Portrayal of Social Media Challenges on YouTube and Twitter. ACM Transactions on Social Computing, 4(1), 1-23. https://doi. org/10.1145/3444961 
Lopes, I., Guarda, T., Victor, J. A., \& Vázquez, E. G. (2020). The Influence of Youtubers in Consumer Behavior. In Rocha, Reis, Peter \& Bogdanović (Edts.) Marketing and Smart Technologies, Smart Innovation, Systems and Technologies, vol. 167 (pp. 49-58). Springer. https://doi.org/10.1007/978981-15-1564-4_6

Lovelock, M. (2017). 'Is every YouTuber going to make a coming out video eventually?': YouTube celebrity video bloggers and lesbian and gay identity. Celebrity Studies, 8(1), 87-103. https://doi:10.10 80/19392397.2016.1214608

Maloney, M., Roberts, S., \& Caruso, A. (2017). 'Mmm ... I love it, bro!': Performances of masculinity in YouTube gaming. New Media \& Society, 20(5), 1697-1714. https://doi.org/10.1177/1461444817703368

Marôpo, L., Sampaio, I. V., \& Miranda, N. P. D. (2017). Top girls on YouTube. In Ilana Eleá \& Lothar Mikos (Eds.), Young \& creative: digital technologies empowering children in everyday life (pp. 65-76). The International Clearinghouse on Children, Youth and Media, University of Gothenburg, Nordicom.

Martínez-Pastor, E., Ongkrutraksa, W., \& Vizcaíno-Laorga, R. (2020). Una aproximación a los niños Youtubers tailandeses. El caso de los menores como prescriptores de juguetes [An analysis of kid YouTubers in Thailand. The case of minors as influencers for toys]. Mediterranean Journal of Communication, 11(1), 213-223. https://www.doi.org/10.14198/MEDCOM2020.11.2.1

Masanet, M. J. (2016). Pervivencia de los estereotipos de género en los hábitos de consumo mediático de los adolescentes: drama para las chicas y humor para los chicos [Persistence of gender stereotypes in the media consumption habits of adolescents: Drama for girls and humor for boys]. Cuadernos. info, 39, 39-53. http://dx.doi.org/10.7764/cdi.39.1027

McRoberts, S., Bonsignore, E., Peyton, T., \& Yarosh, S. (2016). Do It for the viewers!: Audience engagement behaviors of young Youtubers. In Proceedings of the 15th IDC International Conference on Interaction Design and Children, 334-343. https://doi.org/10.1145/2930674.2930676

Mercedes, G. V. M. (2015). Spanish youth and teenagers migrating through social networks. From Tuenti to Facebook and from Facebook to Instagram. The second migration. Icono 14, 13(2), 4872. https://doi.org/10.7195/ri14.v13i2.821

Montes-Vozmediano, M., García-Jiménez, A., \& Menor-Sendra, J. (2018). Los vídeos de los adolescentes en YouTube: Características y vulnerabilidades digitales [Teen videos on YouTube: Features and digital vulnerabilities]. Comunicar, 54(1), 61-69. https://www.doi.org/10.3916/C54-2018-06

Murolo, N. L. (2010). Post-zapping transmite tú mismo. YouTube como la televisión posmoderna [Post-zapping broadcast yourself. YouTube as post-modern television]. Razón y Palabra, 71, 110. https://bit.ly/2Z2tfHE

Pereira, S., Moura, P. F. R. D., \& Fillol, J. (2018). The Youtubers phenomenon: what makes YouTube stars so popular for young people? Fonseca, Journal of Communication, 17, 107-123. https://doi. org/10.14201/fjc201817107123

Pérez-Torres, V., Pastor-Ruiz, Y., \& Abarrou-Ben-Boubaker, S. (2018). YouTuber videos and the construction of adolescent identity. Comunicar, 55, 61-70. https://doi.org/10.3916/C55-2018-06

Regueira, U., Alonso Ferreiro, A., \& Da-Vila, S. (2020). Women on YouTube: Representation and participation through the Web Scraping technique. Comunicar, 63, 31-40. https://doi.org/10.3916/ C63-2020-03. 
Scolari, C. A., \& Fraticelli, D. (2017). The case of the top Spanish Youtubers: Emerging media subjects and discourse practices in the new media ecology. Convergence: The International Journal of Research into New Media Technologies, 25(3), 496-515. https://doi.org/10.1177/1354856517721807

Senft, T.M. (2012). Microcelebrity and the branded self. In J. Hartley, J. Burgess, \& A. Bruns (Eds.), A companion to new media dynamics (pp. 346-354). Wiley Blackwell.

Smith, D. (2017). The tragedy of self in digitised popular culture: The existential consequences of digital fame on YouTube. Qualitative Research, 17(6), 699-714. https://doi.org/10.1177/1468794117700709

Suárez-Álvarez, R., García-Jiménez, A. (2021). Centennials on TikTok: type of video. Analysis and comparative Spain-Great Britain by gender, age, and nationality. Revista Latina de Comunicación Social, 79,1-22. https://www.doi.org/10.4185/RLCS-2021-1503

Suárez-Álvarez, R., García-Jiménez, A., \& Montes-Vozmediano, M. (2021). Analysis of the type of advertising content incorporated in the channels of teenage youtubers. Revista Prisma Social, 34, 40-60. https://revistaprismasocial.es/article/view/4340

Tur-Viñes, V., Núñez-Gómez, P., \& Martínez-Pastor, E. (2019). YouTube, menores y cultura colaborativa. Revisión bibliográfica de la investigación [YouTube, Children, and Collaborative Culture. A Literature Review]. Historia y Comunicación Social, 24(1), 331-351. https://doi.org/10.5209/hics.64498

United Nations Children's Fund (UNICEF, 2020). Adolescencia y juventud. https://www.unicef.org/ spanish/adolescence/index_bigpicture.html

Valderrama, M., \& Velasco, P. (2018). ¿Programando la creación? Una exploración al campo socio-técnico de YouTube en Chile [Programming creation? An exploration of the socio-technical field of YouTube in Chile]. Cuadernos.info, (42), 39-53. https://bit.ly/3i22ivy

Westenberg, W. (2016). The influence of Youtubers on teenagers: a descriptive research about the role Youtubers play in the life of their teenage viewers. Master Thesis. University of Twente.

World Health Organization (WHO, 2020). Desarrollo en la adolescencia [Adolescent development]. Retrieved from https://www.who.int/maternal_child_adolescent/topics/adolescence/dev/es/

Yarosh, S., Bonsignore, E., McRoberts, S., \& Peyton, T. (2016). YouthTube: Youth Video Authorship on YouTube and Vine. Paper presented at 19th ACM Conference on Computer-Supported Cooperative Work and Social Computing (CSCW 2016), San Francisco: USA. 